\title{
ДЕМИНЕРАЛИЗАЦИЯ РАСТВОРА ФЕНИЛАЛАНИНА ЭЛЕКТРОМЕМБРАННЫМИ МЕТОДАМИ
}

\author{
(C) 2017 А. Ю. Харина, С. Я. Елисеев \\ Воронежский государственный университет, Университетская пл., 1, 394018 Воронеж, Россия \\ e-mail: aukharina@gmail.com
}

Поступила в редакцию 24.01.2017 г.

\begin{abstract}
Аннотация. Исследованы параметры эффективности деминерализации растворов алкилароматической аминокислоты - фенилаланина (Phe) и хлорида натрия при использовании методов электродиализа (ЭД) и электродеионизации (ЭДИ). Показаны преимущества турбулентного режима течения жидкости над ламинарным, выражающиеся в достижении больших значений степени обессоливания $(D)$. Способ очистки растворов аминокислоты методом ЭДИ может быть использован как более энергосберегающий, так как при плотностях тока, не превышающих предельную, достигаются значения $D$ больше 70 \%. ЭДИ также позволяет провести глубокое обессоливание раствора фенилаланина в интенсивных токовых режимах, однако, потери целевого продукта при этом увеличиваются.
\end{abstract}

Ключевые слова: алкилароматическая аминокислота, хлорид натрия, электродеионизация, электродиализ, деминерализация.

\section{ВВЕДЕНИЕ}

В настоящее время классический метод электродиализа применяется для различных приложений, например, при опреснении солоноватых вод; деминерализации растворов аминокислот, их концентрировании; осветлении вин - их очистке от солей винной кислоты; разделении органических амфолитов и неэлектролитов. Для увеличения эффективности процесса разрабатываются различные новые конструкции электродиализаторов. Применяются спейсеры $[1,2]$ различного типа в качестве турбулизаторов потока. Профилированные мембраны [3, 4], ионообменные сетки [5], помещаемые в камеры обессоливания, также позволяют интенсифицировать массообменные характеристики.

При использовании гибридного метода электродеионизации, применяемого для получения ультрачистой воды $[6,7]$, секции обессоливания заполняются ионообменниками [8]. В литературе представлено ограниченное количество работ, в которых предлагается использовать метод электродеионизации для обессоливания растворов нейтральных [9], основных [10] и кислых аминокислот [11].

Цель данной работы состоит в исследовании характеристик деминерализации раствора нейтральной алкилароматической аминокислоты методами электродеионизации и электродиализа с гладким каналом обессоливания и каналом, заполненным непроводящим спейсером.

\section{ЭКСПЕРИМЕНТАЛЬНАЯ ЧАСТЬ}

Обессоливание раствора алкилароматической аминокислоты фенилаланина $(0.02 \mathrm{M})$ в смеси с $\mathrm{NaCl}(0.01 \mathrm{M})$ осуществлялось методами электродиализа и электродеионизации. Схемы ячейки для электродиализа с сополимером стирола и дивинилбезола, заполняющим секцию деионизации, и для электродеионизации представлены на рис. $1 a$ и 16. При проведении классического электродиализа секция (4) электродиализатора была свободна от турбулизаторов потока жидкости.

Камеры деионизациии и концентрирования ячейки для обессоливания чередуются и разделены гетерогенными сильнокислотными катионообменными мембранами марки МК-40 и высокоосновными анионообменными мембранами MA-41, изготовленными ООО «Щекиноазот», Россия. Для реализации электродеионизации секция обессоливания 4 заполнялась смешанным слоем из сильнокислотного катионообменника марки Lewatit S1468 и высокоосновного анионообменника Lewatit S6328A, изготовленного LANXESS Deutschland $\mathrm{GmbH}$, Германия. Объемное соотношение катионообменника и анионообменника - 2:3. Ионообменник, способный генерировать ионы гидроксила 


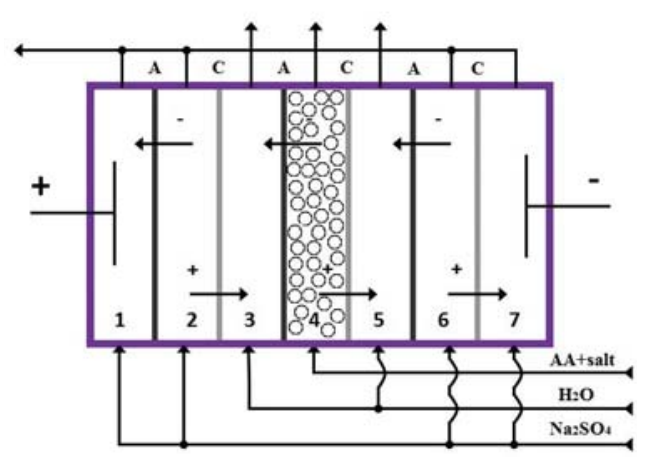

$a$

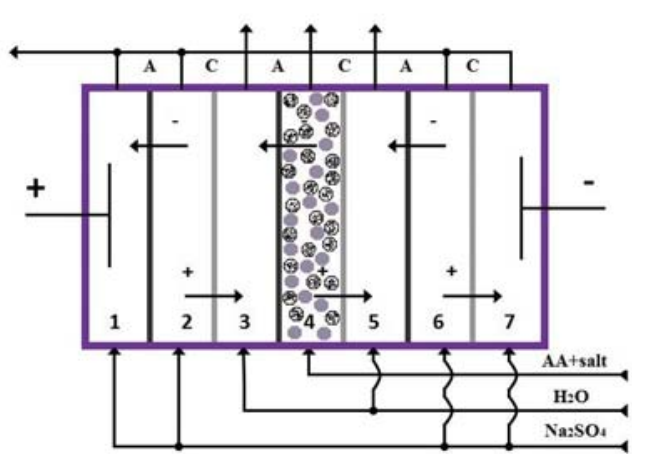

$b$

Рис. 1. Схема ячейки: $a$ ) для электродиализа с засыпкой сополимера стирола и дивинилбезола - $\mathrm{O}, b)$ электродеионизации со смешанным слоем ионообменников: - катионообменник, - анионообменник, С - катионообменные, А - анионообменные мембраны, АА - аминокислота

[Fig. 1. The scheme of the cell: $a$ ) for electrodialysis with nonconductive filler - styrene-divinylbenzene copolymer - $\mathrm{O}$, b) for electrodeionization with ion conductive filler: - cation-exchange resin, - anion-exchange resin, $\mathrm{C}$ - cationexchange membrane and $\mathrm{A}$ - anion-exchange membrane, AA - amino acid]

и гидроксония при достижении предельного диффузионного тока, выступает также в качестве турбулизатора потока. В работе приведены параметры обессоливания раствора аминокислоты при заполнении камеры деионизации инертным турбулизатором потока - сополимером стирола и дивинилбензола (ССД). Геометрические параметры камер электродиализного аппарата: ширина - 0.01 м, высота 0.2 м, рабочая площадь секции $-0.002 \mathrm{~m}^{2}$. Линейная скорость течения жидкости $3.3 \cdot 10^{-4} \mathrm{M} / \mathrm{c}$ поддерживалась перистальтическим насосом. Смешанный раствор аминокислоты Phe (0.02M) и $\mathrm{NaCl}$ (0.01 M) поступал в 4 камеру электродиализатора. Раствор $\mathrm{K}_{2} \mathrm{SO}_{4}$ концентрации 0.1 М пропускался через секции $1,2,6,7$. В камеры концентрирования 3, 5 подавалась дистиллированная вода. Обессоливание раствора аминокислоты осуществлялось в гальваностатическом режиме.

Количественный анализ ионов аминокислоты в растворах, вытекающих из секций $3,4,5$, проводился методом спектрофотометрии. Ионы натрия определялись методом эмиссионной фотометрии пламени, ионы хлора - аргентометрическим титрованием, основанным на реакции образования осадка хлорида серебра, с использованием в качестве индикатора хромат калия.

Расчет степени обессоливания $(D, \%)$ произведен по убыли концентрации компонентов раствора секции обессоливания согласно формуле (1):

$$
D=\frac{C_{\text {исх }}-C_{\text {ост }}}{C_{\text {исх }}} \cdot 100 \%,
$$

где $D$ - степень обессоливания, $C_{\text {исх }}-$ концентрация соли в исходном растворе, моль/дм ${ }^{3} ; C_{\text {ост }}$ - остаточ- ная концентрация соли в секции деионизации при заданной плотности тока, моль /дм ${ }^{3}$.

Потери аминокислоты $(L, \%)$ рассчитывались по аналогичной формуле, где $C_{\text {исх }}-$ концентрация аминокислоты в подаваемом растворе, моль/дм³ $C_{\text {ост }}$ - концентрация аминокислоты в растворе на выходе из секции деионизации при заданной плотности тока, моль/дм ${ }^{3}$.

\section{РЕЗУЛЬТАТЫ И ИХ ОБСУЖДЕНИЕ}

С целью сопоставления показателей эффективности деминерализации раствора алкилароматической аминокислоты фенилаланина в смеси с $\mathrm{NaCl}$ проведено сравнение процессов обессоливания раствора аминокислоты двумя электромембранными методами, такими как электродиализ и электродеионизация.

В данной работе осуществлена оценка степени обессоливания раствора аминокислоты и потерь фенилаланина в гладком канале и канале с турбулизаторами потока жидкости. Зависимости степени обессоливания раствора $\mathrm{Phe}+\mathrm{NaCl}$, рассчитанные по изменению концентрации анионов хлора, от плотности тока для трех рассматриваемых систем представлены на рис. 2.

Применение инертного наполнителя (сополимера стирола и дивинилбензола) в качестве турбулизатора потока приводит к достижению большего значения степени обессоливания, чем при ламинарном потоке жидкости в канале обессоливания при одной плотности тока. Увеличение потока анионов хлора через мембрану МА-41 в диапазоне плотности тока от 0.05 до 5 мА/см² связано с уменьшением затруднений при массопереносе, обуслов- 


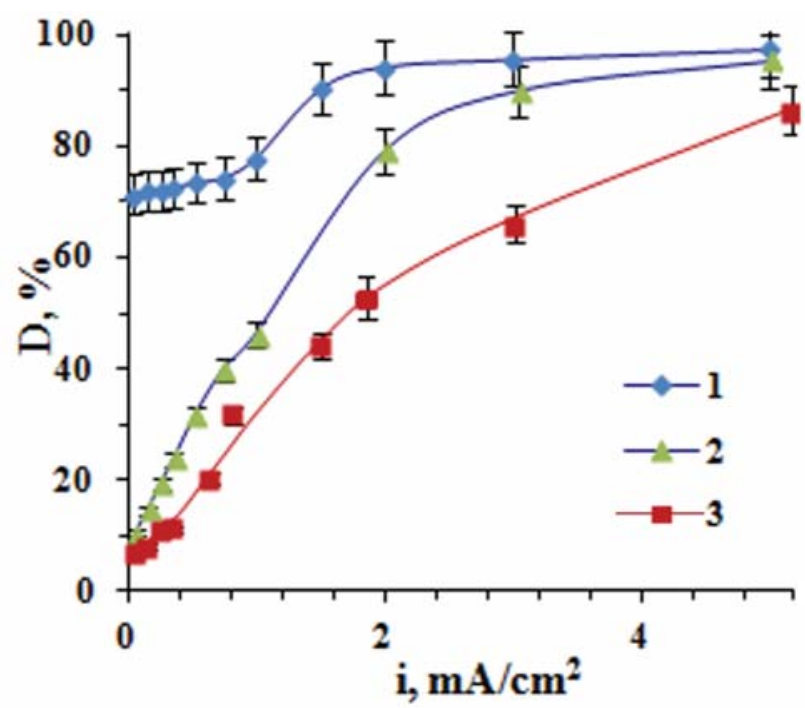

Рис. 2. Зависимость степени обессоливания раствора Phe $(0.02 \mathrm{M})+\mathrm{NaCl}(0.01 \mathrm{M})$ от плотности тока при: 1 - ЭДИ, 2 - ЭД с ССД, 3 - ЭД

[Fig. 2. The dependence of desalination degree of Phe $(0.02 \mathrm{M})+\mathrm{NaCl}(0.01 \mathrm{M})$ solution on the current density in: 1 -EDI, 2 -ED with styrene-divinylbenzene copolymer,

$$
3-\mathrm{ED}]
$$

ленных лимитированием стадии подвода переносчиков электрического тока к поверхности мембраны из объема раствора.

При деминерализации раствора $\mathrm{Phe}+\mathrm{NaCl}$ методом электродеинизации достигаются высокие значения степени обессоливания уже при малых плотностях тока. Это позволяет сократить энергозатраты при очистке раствора аминокислоты от минеральной соли.

Зависимости потерь аминокислоты от плотности тока при деминерализации смешанного раствоpa $\mathrm{Phe}+\mathrm{NaCl}$ показаны на рис. 3 .

При деминерализации растворов аминокислоты рассматриваемыми способами наблюдается нелинейный характер изменения потерь фенилаланина в зависимости от плотности тока. Это связано с особенностями потоков аминокислоты через ионообменные мембраны в зависимости от плотности тока, а именно, с наличием влияния барьерного [12], циркуляционного эффекта [13], эффекта облегченной электромиграции [14]. Снижение массопереноса аминокислоты при действии барьерного эффекта после достижения предельного диффузионного тока может быть использовано для оптимизации процесса очистки раствора аминокислоты методом ЭДИ, так как уже при малых значениях плотности тока в данном случае достигаются довольно высокие значения степени обес-

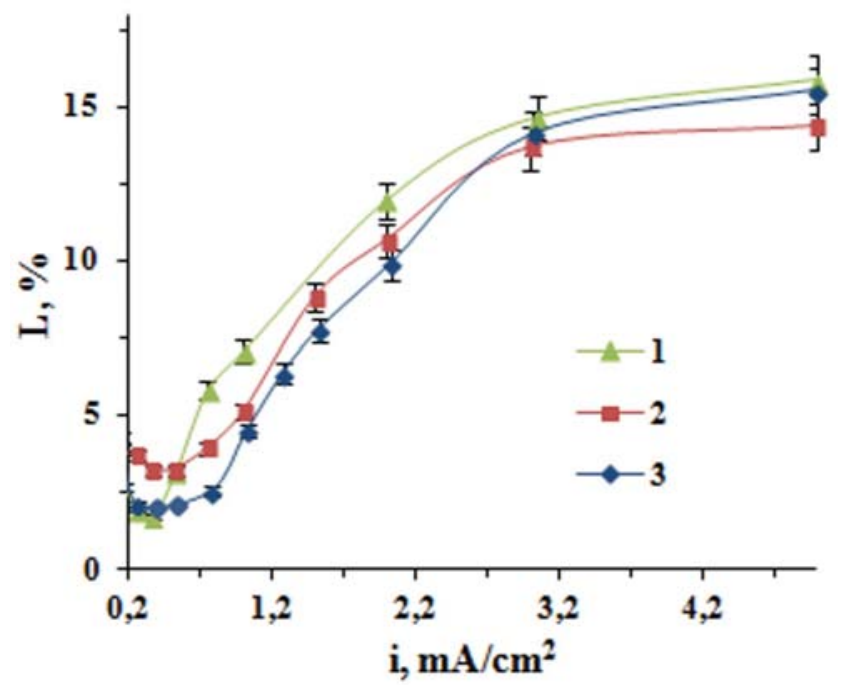

Рис. 3. Зависимость потерь аминокислоты от плотности тока за счет потоков через мембраны МК-40 и МА-41 при обессоливании раствора Phe $(0.02 \mathrm{M})+\mathrm{NaCl}$

$(0.01 \mathrm{M}): 1$ - ЭД с засыпкой ССД, 2 - ЭДИ, 3 - ЭД

[Fig. 3 The dependence of amino acid losses on the current density during the desalination of Phe $(0.02 \mathrm{M})+\mathrm{NaCl}$ (0.01 M) solution: 1 - ED with styrene-divinylbenzene copolymer, 2 - EDI, 3 - ED]

соливания раствора. Влияние эффекта облегченной электромиграции обусловливает увеличение потерь аминокислоты в запредельных условиях электродиализа.

В процессе обессоливания раствора, содержащего фенилаланин, методом электродеиоизации с использованием значений плотности тока, не превышающих предельную, потери амфолита больше, чем при использовании электродиализа с гладим каналом обессоливания и каналом, заполненным сополимером стирола и дивинилбензола. В интенсивном токовом режиме потери аминокислоты при использовании электродиализа с гладким каналом и электродеионизации сопоставимы и отличаются в пределах погрешности эксперимента. Максимальные потери фенилаланина наблюдаются в ходе обессоливания раствора амфолита методом электродиализа с использованием непроводящего спейcepa.

Потоки ионов органического амфолита через ионообменные мембраны зависят от $\mathrm{pH}$ растворов секции обессоливания. В работе проводился контроль изменения $\mathrm{pH}$ растворов секций обессоливания и концентрирования от плотности тока. Сравнение зависимостей $\mathrm{pH}$ растворов секции обессоливания 4, а также секции концентрирования 3 со стороны мембраны МА-41 от плотности тока, зарегистрированных при деминерализации раствора 
алкилароматической аминокислоты для трех исследованных систем, представлено на рис. $4 a$ и 46.

Применение турбулизатора потока - сополимера стирола и дивинилбензола приводит к увеличению предельной диффузионной плотности тока, которая определяется в процессе контроля изменения $\mathrm{pH}$ растворов секции концентрирования со стороны анионообменной мембраны в зависимости от плотности тока по резкому изменению показателя кислотности среды при использовании методики несимметричной концентрационной поляризации [15]. (В промышленных установках для электродеионизации предполагается заполнение всех камер деионизации смешанным слоем ионообменника). В интенсивном токовом режиме увеличивается вклад электроконвективного перемешивания раствора, способствующего интенсификации потока одинаково заряженных компонентов раствора. В процессе электродеионизации также наблюдается смещение предельной диффузионной плотности тока в сторону большего значения. Кроме того, большие потоки аминокислоты через мембрану приводят к достижению меньших значений рН растворов камеры концентрирования 3. Это связано с меньшим потоком ионов гидроксила, образующихся при реакции диссоциации воды на границе мембрана/раствор и участвующих в пере- носе тока.

Снижение лимитирования стадии подвода ионов к поверхности мембраны при ЭД с ССД и при ЭДИ служит причиной изменений на зависимости pH растворов секции обессоливания от плотности тока. Максимум на зависимости рН(i), наблюдаемый при электродиализе ввиду различной подвижности катиона и аниона минеральной соли в растворе [16, 17], отсутствует при ЭДИ и ЭД с ССД. Кроме того, при ЭДИ происходит наименьшее защелачивание раствора камеры (4) электродиализатора.

Рассчитанные степень обессоливания, потери аминокислоты, достигаемые при использовании различных способов обессоливания раствора алкилароматической аминокислоты и минеральной соли, приведены в табл. 1.

Из представленных данных видно, что при использовании классического электродиализа значения степени обессоливания достигают наименьших значений при потерях аминокислоты, не значительно отличающихся по сравнению с методом электродеионизации и ЭД с ССД.

Для глубокого обессоливания раствора аминокислоты применение методов ЭДИ и ЭД с ССД в интенсивных токовых режимах наиболее целесообразно. Сокращение потерь целевого продукта и энергозатрат в процессе деминерализации раство-

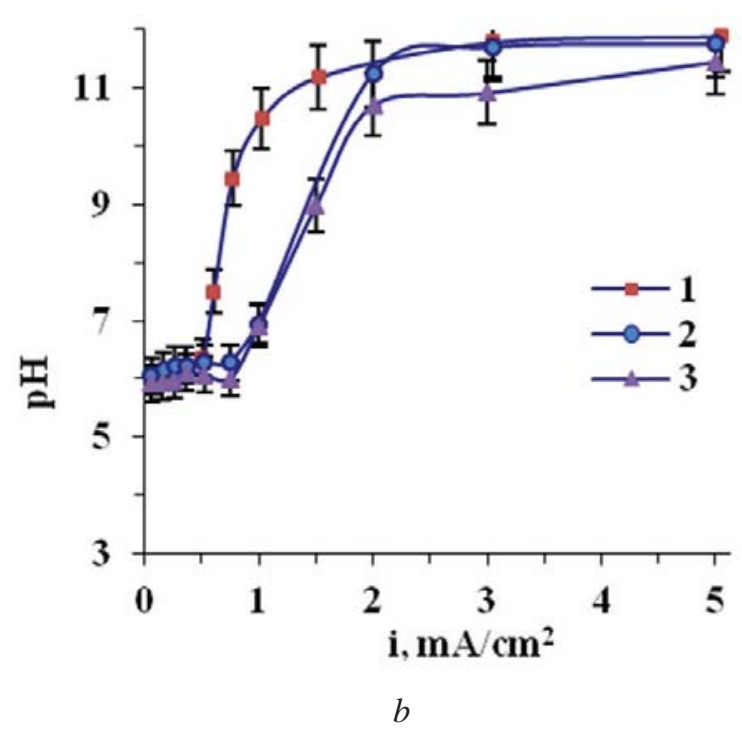

Рис. 4. Зависимость рН от плотности тока при обессоливании смешанного раствора $\mathrm{Phe+} \mathrm{NaCl}$ для секций: $a$ ) обессоливания в процессах: 1 - ЭДИ, 2 - ЭД с ССД, 3 - ЭД; б) концентрирования со стороны мембраны МА-41 в процессах: 1 - ЭД, 2 - ЭД с ССД, 3 - ЭДИ

[Fig. 4. The dependences of solution $\mathrm{pH}$ on the current density during desalination of $\mathrm{Phe}+\mathrm{NaCl}$ solution for the sections: a) desalination in the processes : 1 - EDI, 2 - ED with styrene-divinylbenzene copolymer, 3 - ED; $b$ ) concentration in the processes: 1 - ED, 2 - ED with styrene-divinylbenzene copolymer, 3 - EDI] 
Таблица 1. Степень обессоливания и потери аминокислоты при деминерализации раствора Phe $(0.02 \mathrm{M})+$ $\mathrm{NaCl}(0.01 \mathrm{M})$ электромембранными методами в зависимости от плотности тока

[Table 1. Desalination degree and amino acid losses in desalination of Phe $(0.02 \mathrm{M})+\mathrm{NaCl}(0.01 \mathrm{M})$ solution by electro membrane methods at various values of current density]

\begin{tabular}{|c|c|c|c|c|c|c|}
\hline \multirow{2}{*}{$\begin{array}{c}i, \mathrm{MA} / \mathrm{cm}^{2} \\
{\left[i, \mathrm{~mA} / \mathrm{cm}^{2}\right]}\end{array}$} & \multicolumn{2}{|c|}{$\begin{array}{c}\text { ЭДИ } \\
{[\mathrm{EDI}]}\end{array}$} & \multicolumn{2}{c|}{$\begin{array}{c}\text { ЭД } \\
{[\mathrm{ED}]}\end{array}$} & $\begin{array}{c}\text { ЭД с ССД } \\
\text { [ED with styrene- } \\
\text { divinylbenzene copolymer] }\end{array}$ \\
\cline { 2 - 7 } & $L, \%$ & $\alpha, \%$ & $L, \%$ & $\alpha, \%$ & $L, \%$ & $\alpha, \%$ \\
\hline 0.26 & 3.7 & 72.1 & 2.1 & 10.9 & 2 & 19.5 \\
\hline 0.36 & 3.2 & 72.6 & 2.0 & 11.4 & 1.7 & 23.8 \\
\hline 0.525 & 3.2 & 73.5 & 2.2 & 20.5 & 3.2 & 31.4 \\
\hline 1.00 & 5.1 & 77.9 & 4.5 & 35.5 & 7.1 & 46.2 \\
\hline 2.00 & 10.6 & 94.2 & 9.9 & 48 & 12 & 79.0 \\
\hline 3.00 & 13.7 & 95.6 & 14.1 & 65.9 & 14.6 & 90.0 \\
\hline 5.00 & 14.4 & 97.3 & 15.5 & 86.4 & 15.9 & 95.2 \\
\hline
\end{tabular}

ра аминокислоты методом электродеионизации возможно при плотностях тока, соответствующих действию барьерного эффекта.

\section{ЗАКЛЮЧЕНИЕ}

Деминерализация раствора аминокислоты методом электродиализа с применением турбулизаторов по сравнению с гладким каналом обессоливания является наиболее перспективной, ввиду получения раствора аминокислоты с большей степенью чистоты. Преимуществом метода электродеионизации наряду с увеличением степени обессоливания является возможное сокращение энергозатрат по сравнению с классическим электродиализом, так как более высокие значения степени обессоливания, превышающие 70 \% (по анионам), достигаются при плотностях тока меньше предельной.

Работа выполнена при финансовой поддержке «Фонда содействия развитию мальх форм предприятий в научно-технической сфере», программа «УМНИК», договор 10032Г 'У2/2015.

\section{СПИСОК ЛИТЕРАТУРЫ}

1. Kedem O. // Desalination, 1975, vol. 16, p. 105.

2. Shaposhnik V. A., Grigorchuk O. V., Korzhov E. N., Vasil'eva V. I., Klimov V. Ya. // J. Membr. Sci., 1998, vol. 139, p. 85.

3. Белобаба А. Г., Певницкая М. В., Козина А. А., Нефедова Г. З., Фрейдлин Ю. Г. // Известия СО АН СССР. Сер. Хим. Наук, 1980, т. 4, вып. 12, № 9, с. 161-
165.

4. Заболоцкий В. И., Лоза С. А., Шарафан М. В. // Электрохимия, 2005, т. 41, № 10, с. 1185-1192.

5. Shaposhnik V. A., Zubets N. N., Mill B. E., Strigina I. P. // Desalination, 2001, vol. 133, p. 211.

6. Гнусин Н. П., Гребенюк В. Д., Электрохимия гранулированных ионитов, Наукова Думка, Киев, 1972, $180 \mathrm{c}$.

7. Messalem R. L., Mirsky Y., Daltrophe N., Saveliev G., Kedem O. // J. Membr. Sci., 1998, vol. 138, p. 171.

8. Alvarado L., Chen A. // Electrochim. Acta, 2014, vol. 132, p. 583.

9. Лущик И. Г., Елисеева Т. В., Шапошник В. А., Терешенко А. С. // Сорбиионные и хроматографические проиессы, 2003, № 3, с. 722-730.

10. Eliseeva T. V., Shaposhnik V. A., Krisilova E. V., Bukhovets A. E. // Desalination, 2009, vol. 241, p. 86.

11. Yuan F., Wang Q., Yang P., Tian Yu., Cong W. // Separation and Purification Technology, 2015, vol. 153, p. 51.

12. Войтович И. М., Шапошник В. А., Котов В. В. // Теория и практика сорбционных процессов, 1976, № 11, c. $106-108$.

13. Елисеева Т. В., Шапошник В. А. // Электрохимия, 2000, т. 36, № 1, c. 73-79.

14. Шапошник В. А., Елисеева Т. В., Текучев А. Ю., Лущик И. Г. // Электрохимия, 2001, т. 37, № 2. с. 195201.

15. Шапошник В. А. Кинетика электродиализа. Воронеж, ВГУ, 1989, $176 \mathrm{c}$.

16. Справочник по электрохимии. / Под ред. А. М. Сухотина. Л., Химия, 1981. 488 с.

17. Элькинд К. М., Трунова И. Г. // Труды Нижегородского государственного технического университета им. Р. Е. Алексеева, 1997, № 4, с. 272-279. 


\title{
DESALINATION OF PHENYLALANINE SOLUTION BY ELECTRO MEMBRANE METHODS
}

\author{
(C) 2017 A. Yu. Kharina, S. Ya. Eliseev \\ Voronezh State University, Universitetskaya sq, 1, 394018 Voronezh, Russia \\ e-mail: aukharina@gmail.com
}

Received 24.01.2017

\begin{abstract}
Desalination of phenylalanine solution with mineral salt impurity by electro membrane methods is studied in this paper. The parameters of desalination efficiency such as desalination degree and ampholyte losses in electrodialysis with empty deionization channel and with spacers are compared in the process of desalination of solution containing phenylalanine and sodium chloride.

The experiments have been carried out in a seven compartment electrodialyzer with heterogeneous monopolar ion-exchange membranes. Electrodialysis cell has equipped with anion-exchange membranes MA-41 and cation-exchange membranes MK-40 manufactured by "Shchekinoazot" Ltd, Russia. Two types of spacers are filled in desalination compartment.

An inert filler - styrene-divinylbenzene copolymer as turbulator in electrodialysis cell is used to achieve larger value of the desalination degree than that for laminar fluid flow in the desalting channel of electrodialyzer. The high values of the desalination degree of mixed solution $\mathrm{Phe}+\mathrm{NaCl}$ are reached at current densities below the limiting one by using EDI. This method can be used as more energysaving technology.

The mass transfer of organic ampholyte ions through ion-exchange membranes depends on the solution $\mathrm{pH}$ of the desalting section. In electrodialysis with spacers in desating channel the value of the limiting current density increases and the change of solution $\mathrm{pH}$ of deionization compartment decreases. This is due to the reducing of the diffusion limitation of ions movement from bulk solution to the membrane surface.

Desalination of amino acid solution by electrodialysis with ionconductive and nonconductive spacers is more perspective for obtaining of amino acids solutions with a higher degree of purity.
\end{abstract}

Keywords: alkyl aromatic amino acid, sodium chloride, electrodeionization, electrodialysis, demineralization.

\section{ACKNOWLEDGEMENTS}

The work was supported by the "Foundation for Assistance to Small Innovative Enterprises in Science and Technology", the program "UMNIK" contract $10032 G U 2 / 2015$.

\section{REFERENCES}

1. Kedem O. Desalination, 1975, vol. 16, p. 105. DOI: 10.1016/S0011-9164(00)84095-3

2. Shaposhnik V. A., Grigorchuk O. V., Korzhov E. N., Vasil'eva V. I., Klimov V. Ya. J. Membr. Sci., 1998, vol. 139, p. 85. DOI: 10.1016/S0376-7388(97)00247-0

3. Belobaba A. G., Pevnitskaya M. V., Kozina A. A., Nefedova G. Z., Freidlin Yu. G. In Russian Chemical Bulletin, 1980, vol. 4, iss. 12, no. 9, pp. 161-165.

4. Zabolotskii V. I., Loza S. A., Sharafan M. V. Elektrokhimiya, 2005, vol. 41, no. 10, pp. 1185-1192.

5. Shaposhnik V. A., Zubets N. N., Mill B. E., Strigina I. P. Desalination, 2001, vol. 133, p. 211. DOI: 10.1016/ S0011-9164(01)00101-1
6. Gnusin N. P., Grebenyuk V. D. Electrochemistry of Granular Ion Exchangers. Kiev, Naukova Dumka Publ., 1972. 180 p. (in Russian)

7. Messalem R. L., Mirsky Y., Daltrophe N., Saveliev G., Kedem O. J. Membr. Sci., 1998, vol. 138, p. 171. DOI: 10.1016/S0376-7388(97)00217-2

8. Alvarado L., Chen A. Electrochim. Acta, 2014, vol. 132, p. 583. DOI: 10.1016/j.electacta.2014.03.165

9. Lushchik I. G.., Eliseeva T. V., Shaposhnik V. A., Tereshenko A. S. Sorption and Chromatographic Processes, 2003, vol. 3, pp. 722-730. (in Russian)

10. Eliseeva T. V., Shaposhnik V. A., Krisilova E. V., Bukhovets A. E. Desalination, 2009, vol. 241, p. 86. DOI: 10.1016/j.desal.2008.02.030

11. Yuan F., Wang Q., Yang P., Tian Yu., Cong W. Separation and Purification Technology, 2015, vol. 153, p. 51. DOI: 10.1016/j.seppur.2015.08.036

12. Voitovich I. M., Shaposhnik V. A., Kotov V. V. Theory and Practice of Sorption Processes, 1976, no. 11, pp. 106-108. (in Russian) 
13. Eliseeva T. V., Shaposhnik V. A. Russian Journal of Electrochemistry, 2000, vol. 36, no. 1, pp. 64-67. (in Russian)

14. Shaposhnik V. A., Eliseeva T. V., Tekuchev A. Yu., Lushchik I. G. Russian Journal of Electrochemistry, 2001, vol. 37, no. 2. pp. 170-175. (in Russian)

15. Shaposhnik V. A. Kinetics of Electrodialysis. Voronezh, VSU Publ., 1989, 176 p. (in Russian)
16. Handbook of Electrochemistry. / Ed. A. M. Sukhotina. L., Chemistry Publ., 1981. 488 p. (in Russian)

17. El'kind K. M., Trunova I. G. Proceedings of the Nizhny Novgorod State Technical University named after R. E. Alekseeva, 1997, no. 4, pp. 272-279. (in Russian)
Харина Анастасия Юрьевна - аспирант кафедры аналитической химии, Воронежский государственный университет; тел.: +7 (4732) 208932, e-mail: aukharina@ gmail.com

Елисеев Сергей Яковлевич - к. х. н., старший преподаватель 73 кафедры ВУНЦ ВВС ВВА, Воронеж.
Kharina Anastasiia Yu. - postgraduate student, Department of Analytical Chemistry, Voronezh State University; ph.: +7 (4732) 208932, e-mail: aukharina@ gmail.com

Eliseev Sergey Ya. - Cand. Sci. (Chem.), Assistant Professor, Department 73, Voronezh Educational and Scientific center VVS VVA. 